\title{
Relationship between information asymmetry and cost of capital
}

\author{
Hosein Kazemi ${ }^{\mathrm{a}}$ and Fateme Rahmani ${ }^{*}$
}

\begin{abstract}
${ }^{a}$ Assist. Prof. \& Faculty Member, Department of Accounting, School of Management and Accounting, Ghazvin Branch, Islamic Azad University (IAU), Ghazvin, Iran

${ }^{b}$ M.A. Student, Department of Accounting, School of Management and Accounting, Ghazvin Branch, Islamic Azad University (IAU), Ghazvin, Iran

A R T I C LE I N F O

Article history:

Received March 28, 2012

Received in revised format

19 October 2012

Accepted 20 October 2012

Available online

October 202012

Keywords:

Cost of capital

Informational asymmetry

Bid-ask spread
\end{abstract}

\section{Introduction}

Financial statements are intended to provide some necessary information for users to make economical decisions. Appropriate and relevant information is one of the effective factors in decision making and it is getting challenging task to make financial decisions whenever the required information is asymmetrically distributed. Thus, it is necessary to always carefully monitor the quality of information distribution (Qaemi \& Vatan-Parast, 2005). Investors as suppliers of capital for firms are interested in information on inherent risk and return on their investment. They require information to make appropriate decisions on purchasing, holding or selling shares and evaluate firm's performance associated with dividend payout. Shareholders in their status as the main users of financial statements see the benefit of obtaining perfect, accurate and transparent information. Agency problems, e.g. informational asymmetry between owners and managers and risk of adverse selection, result in necessity of perfect and accurate information for shareholders. If financial

* Corresponding author.

E-mail addresses: a.frahmani@yahoo.com (F. Rahmani)

(C) 2013 Growing Science Ltd. All rights reserved.

doi: $10.5267 /$ j.msl.2012.10.026 
statements provide incomplete and unclear information, this leads to uncertainty among shareholders and the resulted uncertainty, in turn, creates risks and consequently significant stock price fluctuations (Francis et al., 2004).

\section{Background}

In 1970, three scholars named Michael Spence, George Akerlof, Joseph Stiylitz (winners of Nobel prize in economics in 2001) founded a theory on information economy known as asymmetric information. Akerlof demonstrated that informational asymmetry can lead to increased adverse selection in markets and this is the case before conduction of transactions. Spence noted that informed intermediaries are able to increase their market revenues by communicating their confidential information to low-informed ones. Akerlof drew a picture in which seller had more information than buyer did. Of course, accountants have resorted to perfect disclosure policy to mitigate adverse selection problem with the aim of an increase in information available to public (Mokarrami, 2002).

Fu et al. (2011) studied the impact of financial reporting frequency on informational asymmetry and cost of capital. Lambert and Verecchia (2010) studied the role played by information with respect to pricing and cost of capital in partial competitive markets. Their results demonstrated that interaction between partial competitive markets and informational asymmetry increased the impact of information on cost of capital. Lambert et al. (2007) explained that accounting information exerted its impacts on corporate capital cost in two ways:

1- Direct effects, which is the case when high-quality accounting information does not influence cash flows per se but influences the extent of distribution of cash flows by market participants.

2- Indirect effects in which high-quality accounting information influences actual decisions of a firm which have effects on corporate expected value and cash flow variance.

In addition, they showed that information quality had a direct impact on corporate expenditure of capital and improvement of information quality clearly reduces the systematic risk. This finding is of importance because it shows that beta coefficient of a firm is a function of information quality and disclosure of it (Lambert et al., 2007).

Lambert et al. (2006) studied the relationship between informational asymmetry among investors and cost of capital. Their results showed that in case of perfect competition, informational asymmetry among investors influences cost of capital through informational accuracy not information itself. Also in case of partial competition, informational asymmetry influences willingness to offer cash flow and this in turn has impacts on cost of capital. Hughes et al. (2005) studied the relationship between informational asymmetry, diversification and cost of capital. They showed that in large economies, confidential information on systematic factors influences risk premium only through its effect on risk premium factor. High informational asymmetry can also lead to a high-risk premium factor and, in turn, it can increase cost of capital. Non-systematic risk and related confidential information are diversifiable and thus they have no impacts on cost of capital.

Cohen (2003) evaluated the nature of corporate financial reporting choices and then studied the impacts of these choices on cost of capital for corporate common stock. From Cohen's view, though preparation of high quality financial reports reduces informational asymmetry and finally it can lead to decreased cost of capital but many business units take a position opposite to maximization of reporting quality.

Easley and O'Hara (2001) studied the effect of information in capital cost and concluded that difference in informational mix with respect to share of confidential versus public information 
impacts cost of capital and investors expect more return for holding shares with higher level of confidential information. This higher return shows the fact that confidential information increases the risk of holding shares for non-informed investors because informed ones are better able to include new information in their portfolio.

Diamond and Verrecchia (1991) studied the relationship between disclosure, liquidity and cost of capital and their results show that disclosure of public information can reduce informational asymmetry substantially and in this way reduce corporate expenditure of capital by attracting higher demand from major investors due to increased liquidity of corporate securities.

\section{Research Hypothesis}

In present research, the relationship between cost of capital and informational asymmetry is studied to see whether informational asymmetry influences cost of capital. In order to reply the abovementioned question and according to theoretical bases in this field some hypotheses were formulated as following:

1- There is a significant relationship between market competition, informational asymmetry and cost of capital.

2- Firms with higher informational asymmetry have higher cost of capital than those with lower one.

3- When partial markets exist and firm has a high (low) informational asymmetry it is predicted that the firm has a high (low) cost of capital. Therefore, it is expected that in partial markets, there is a difference between firms with high informational asymmetry and those with low one with respect to cost of capital. Third hypothesis is formulated in this way: there is a positive relationship between informational asymmetry and cost of capital in partial competitive markets.

4- When markets are perfectly competitive, despite the level of informational asymmetry no investments in market influence the price during transactions. Since no investors can individually influence the price, difference in information among investors has no effects on cost of capital. In other words in case of perfect competition, market risk explains cost of capital in both high and low informational asymmetry contexts. Therefore, there are no differences in cost of capital. Thus, $\mathrm{H}_{4}$ is formulated as this: there is not a significant relationship between informational asymmetry and cost of capital in perfect markets.

\section{Research Methodology}

\subsection{Study Type and Hypothesis Evaluation Method}

Present research is of correlational type because it tests the relationship between independent and dependent variables. In present research, hypotheses were tested using multiple regression models, pairwise comparisons and t- and f-statistics. In addition, software Eviews was used to test research hypotheses. From temporal viewpoint present research is a retrospective study.

\subsection{Instrument for Data Collection and Analysis}

In order to collect information and data two library and field methods were used. For theoretical basis and research background, various papers from internet and books, theses and specialized journals in English or Persian available to researchers were exploited. To calculate research variables actual and predicted information of firms being members of statistical population are required. Financial information required to calculate research variables e.g. date of seasonal earnings announcement, transactional statistics (including final price, number of transactions, market value and total 
transactions), price index, ratio of cash dividends and other corporate announcements (including formation of public forums, etc.) were gathered by referring to the Exchange company website, Audit Organization, financial statements and reports of directing board activities using softwares RahAvard-E-Novin and Tadbir-Pardaz. The collected information was initially sorted and processed by software Excel and then was subjected to analysis by software Eviews.

\subsection{Statistical Population and Study Sample}

In present study, statistical population consisted of all firms listed in Tehran Securities Exchange from 2005 up to end of 2010. Given the six-year period of present study, subjects should be selected in such a way that they have been active during this period so that the hypotheses can be tested. In this respect, the following requirements were applied to selection of subjects:

1- Subject firm should have been listed in Tehran Securities Exchange from 2005 up to the end of 2010 and not delisted during this period.

2- Subject firm should not have any changes in its fiscal year or business during the studied period.

3- For purpose of comparability, fiscal year of firm subject should be ended in March $19^{\text {th }}$.

4- In each studied year, the firm's stock should have been transacted at least once so that its market price is known at the end of fiscal year.

5- Financial information of firm should be available.

6- Firm should not have a transactional lag more than three months.

7- Firm should not be a financial intermediary (investment) firm.

Given the above requirements 109 firms were selected as statistical sample.

\subsection{Research Model}

The results of testing the first hypothesis $H_{1}$

Using Eq. (1), the relationship between stock market competition, informational asymmetry and cost of capital is studied and based on significance of $\beta 3, \mathrm{H}_{1}$ is rejected or supported.

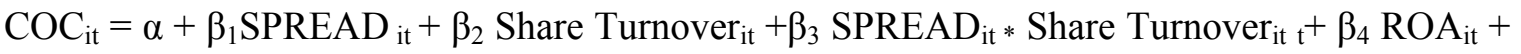
$\beta_{5} \mathrm{M} / \mathrm{B}_{\mathrm{it}}+\beta_{6} \mathrm{LEV}_{\mathrm{it}}+\varepsilon_{\mathrm{it}}$

Testing the second hypothesis (H2)

Firms are ordered based on informational asymmetry. Top 40 percent are considered as firms with high informational asymmetry and bottom 40 percent are considered as firms with low informational asymmetry. Then two-sample t-test is conducted for cost of capital of two mentioned groups so that the relationship between informational asymmetry and cost of capital is determined.

Testing $\mathrm{H}_{3}$ and $\mathrm{H}_{4}$

Firms of the sample were ordered based on market competition and top 40 percent were considered as firms with perfect competition. In addition bottom 40 percent were considered as firms with partial competition and finally tests of the following model were conducted on both groups. 
$\mathrm{COC}_{\mathrm{it}}=\alpha+\beta_{1} \mathrm{SPREAD}_{\mathrm{it}}+\beta_{2} \mathrm{ROA}_{\mathrm{it}}+\beta_{3} \mathrm{M} / \mathrm{B}_{\mathrm{it}}+\beta_{4} \mathrm{LEV}_{\mathrm{it}}+\varepsilon_{\mathrm{i}}$

\subsection{Evaluation of Research Variables}

COCit: cost of capital for common stock calculated based on Omran and Pointon's model.

$$
K_{e}^{c}=\frac{1}{P / E-\left(e_{0}-d_{0}\right) / e_{0}},
$$

$\mathrm{e}_{0}$ : net profit per share at the beginning of financial period,

$\mathrm{d}_{0}$ : dividends per share at the beginning of financial period,

P: final price per share in financial period,

E: net profit per share at the end of financial period.

Debt cost is also calculated as follows:

At first interest rate is calculated by dividing financial costs based on income statement at the end of each year into aggregated interest-bearing liabilities including current financial liabilities, long-term payable notes and long-term financial liabilities based on current year balance sheet multiplied by 1-t.

Tax rate is calculated by dividing profits tax expense into profit before interest and tax calculated from income statement at the end of the year. Finally, average weighted capital cost is obtained multiplying book values of liabilities by common stock at their own cost rates.

SPREADit: bid-ask spread of share of firm I at period t.

In order to estimate informational asymmetry at Tehran Securities Exchange the following model was used. This model was used by Chiang and Vinkatesh (1986) for determining bid-ask spread. Since then other scholars also used this model. The mentioned model is as following:

SPREADit $=\frac{A P-B P}{(A P-B P)^{2}} \times 100$

$t=$ Study period

$i=$ study subject

AP(ASK PRICE): Average ask spread per share of firm $i$ in period $t$.

BP(BID PRICE): Average bid spread per share of firm $i$ in period $t$.

To perform related calculations at first the best bid-ask spread per share is extracted for 21 days before and after announcement of earnings estimated per share and after calculation of bid-ask spread per share, figures obtained for each subject pre- and post- earnings announcement are averaged. If average bid-ask spread per share is equal to 0 , this shows presence of informational asymmetry associated with earnings announcement and otherwise it shows lack of informational asymmetry.

Share Turnoverit: average share turnover of firm $i$ in period $t$ (measure of market competition). Share turnover is used to measure the extent of trading activity. If share turnover is associated with a more competitive market, then firms with high (low) turnover are the most (least) competitive ones (Armstrong et al., 2010). 
Share Turnoverit $=\frac{\text { Annual transaction volume }}{\text { Average issued shares }}$

$i=$ study subject

$t=$ study period

Share turnoverit=average turnover of firm $i$ in period $t$.

$\mathrm{ROA}_{\mathrm{it}}$ : Return on total assets for firm $i$ in year $t$, which is calculated by dividing net profit into total assets.

$M \backslash B_{i t}$ : obtained by dividing market value per share into book value per share for firm $\mathrm{i}$ in year $\mathrm{t}$.

$\mathrm{LEV}_{\mathrm{it}}=$ Leverage obtained by dividing total liabilities to total assets of firm $\mathrm{i}$ in year $\mathrm{t}$ and is a factor influencing cost of capital because liabilities exert a direct effect on cost of capital.

\section{Research Findings}

$\mathrm{H}_{1}$ addresses the relationship between market competition, informational asymmetry and cost of capital as also can be observed in Table1.

Table1

Results of estimation of model1

\begin{tabular}{lccc}
\hline & $\begin{array}{c}\text { Coefficient } \\
\text { variable }\end{array}$ & t-statistic & Error level \\
\hline intercept & 7.99 & 7.6 & 0.000 \\
Informational asymmetry & 0.042 & 15.249 & 0.000 \\
Share turnover & -0.007 & 6.173 & 0.006 \\
Product of Informational asymmetry and share turnover & -0.004 & 7.285 & 0.001 \\
Ratio of market value to book value per share & -0.402 & 5.565 & 0.57 \\
Asset return & -1.81 & -8.846 & 0.000 \\
leverage & -64.08 & -4.26 & 0.000 \\
Adjusted determination coefficient & & 0.096 & \\
f-statistics (error level) & & $16.1(0.0000)$ & \\
Durbin-Watson statistic & & 2.12 \\
\hline
\end{tabular}

Given value of f-statistics (16.5) and its error level (0.000) it can be said that totally the model is of high significance. Also with respect to adjusted determination coefficient (0.9) it can be said that in total more than $9 \%$ of variation in dependent variable is explained by independent variables. In addition according to value of Durbin-Watson statistic (2.12) it can be said that there is not a first order autocorrelation among residuals of research model. According the results obtained from model estimation, contribution of variable market competition to informational asymmetry ( $\alpha 3)$ is -0.004 and based on p-value (0.001) which is less than acceptable error level (0.05) this hypothesis is supported at confidence level of $95 \%$. In other words it can be said that there is a significant relationship between market competition, informational asymmetry and cost of capital. $\mathrm{H}_{2}$ addresses the question of whether firms with higher informational asymmetry have greater cost of capital than those with low informational asymmetry. In order to compare cost of capital for firms from two group's independent two sample t-test was used which its results are shown in Table2.

Table 2

Results of pairwise test

\begin{tabular}{|c|c|c|c|}
\hline Paired variables & t-statistics & Degree of freedom & $\begin{array}{l}\text { Low and high informational } \\
\text { asymmetry }\end{array}$ \\
\hline $\begin{array}{l}\text { Cost of capital for two groups of low and } \\
\text { high informational asymmetry }\end{array}$ & 2.67 & 522 & 0.002 \\
\hline
\end{tabular}


It should be explained that $\mathrm{H}_{0}$ of this test is based on parity of two groups' averages. According to obtained result and significant level, which is less than 5\%, parity of averages of two populations is rejected and it can be concluded that the averages of two populations are significantly different and this confirms the studied hypothesis.

$\mathrm{H}_{3}$ and $\mathrm{H}_{4}$ address the relationship between informational asymmetry and cost of capital in firms with various market competition environments. It is expected that in markets with partial competition, there is a positive relationship between informational asymmetry and cost of capital and $\mathrm{H}_{3}$ addresses this issue. In addition, it is expected that in markets with perfect competition, there is not a positive relationship between informational asymmetry and cost of capital and $\mathrm{H}_{4}$ addresses this issue.

Table 3

Results of estimation of model 2 for study of $\mathrm{H}_{3}$ and $\mathrm{H}_{4}$

\begin{tabular}{lllll}
\hline & $\begin{array}{l}\text { Group of firms } \\
\text { competitive market }\end{array}$ & in partially & $\begin{array}{l}\text { Group of firms in perfectly } \\
\text { competitive market }\end{array}$ \\
\cline { 2 - 5 } variable & Variable coefficient & Error level & Variable coefficient & Error level \\
\hline Intercept & 22.43 & 0.000 & 29.87 & 0.000 \\
Informational asymmetry & 0.175 & 0.000 & -0.0001 & 0.124 \\
Ratio of market value to book value per share & 2.04 & 0.000 & 1.83 & 0.000 \\
Assets return & -0.73 & 0.000 & -1.72 & 0.000 \\
leverage & -14.09 & 0.039 & -96.44 & 0.000 \\
Adjusted determination coefficient & 0.365 & & 0.299 & \\
f-statistics (error level) & $38.52(0.000)$ & & $28.95(0.000)$ & \\
Durbin-Watson statistic & 2.19 & & 1.67 & \\
\hline
\end{tabular}

According to the results obtained from model estimation for group of firms in partial competition markets coefficient for variable of informational asymmetry is 0.175 . In addition, based on p-value of 0.000 , which is less than error level of 0.01 it can be said that there is a significant relationship between informational asymmetry and cost of capital of firms in partial competitive markets. According to the results obtained from model estimation for group of firms in perfect competition, markets coefficient for variable of informational asymmetry is 0.000 and based on p-value of 0.000 . This is less than error level of 0.01 and it can be said that there is not a significant relationship between informational asymmetry and cost of capital of firms in perfect competitive markets and this is consistent with $\mathrm{H}_{4}$.

\section{Conclusion}

In this paper, we present an investigation to find out whether informational asymmetry has any effect on cost of capital. According to research findings, it can be said that in Tehran Securities Exchange, firms with high informational asymmetry have greater costs of capital than those with low informational asymmetry. Therefore, it can be argued that informational asymmetry impacts cost of capital. In addition, the results showed that when capital markets are perfectly competitive, there is not a significant relationship between informational asymmetry and cost of capital but when markets are partially competitive, there is a significant relationship between informational asymmetry and cost of capital. Our results also have demonstrated that the extent of market competition is a major moderating factor influencing the relationship between informational asymmetry and cost of capital.

\section{References}

Armstrong, C., Core, J.E., Taylor, D.J., \& Verrecchia, R.E. (2011). When Does Information asymmetry Affect The Cost Of Capital? Journal of Accounting Research, 49, 1-40. 
Fu, R., Kraft, A. \& Zhang, H. (2012). Financial reporting frequency, information asymmetry and the cost of equity. Journal of Accounting and Economics, to appear.

Cohen, D. (2003). Quality Of Financial Reporting Choice: Determinants And Economic Consequences, Northwestern University, Working Paper Northwestern University Available At Url.

Diamond, D. W., \& Verrecchia, R. E. (1991). Disclosure, Liquidity, And The Cost Of Capital. The Journal of Finance, 46(4), 1325-1359.

Easley, D., \& O'hara, M. (2001). Information and the cost of capital. Working Paper, Cornell University.

Francis, J., Lafond, R., Olsson, P., \& Schiper, K. (2004). Cost of equity and earnings attributes. The Accounting Review, 79, 967- 1010.

Hughes, J., Liu, J., \& Liu, J. (2005). Information asymmetry, diversification, and cost of capital. Accounting Review, 82, 705-729.

Mokarrami, Y. (2002). Asymmetric information theory. Accountant Quarterly, 16, 42-44

Lambert, R., Leuz, C., \&Verrecchia, R. (2006). Information Asymmetry, Information Precision, And The Cost Of Capital. Working Paper, Wharton School.

Lambert, R., Leuz, C., \& Verrecchia, R. (2007). Accounting information, disclosure, and the cost of capital. Journal of Accounting Research, 45, 385-420.

Lambert, R., \& Verrecchia, R. (2010). Cost of capital in imperfect competition settings. Working paper, University Of Pennsylvania, October 2010.

Qaemi, M.H., \& Vatan Parast, M.R. (2005). Study of the role of accounting information in reduction of informational asymmetry at Tehran Securities Exchange. Quarterly of Accounting and Auditing Studies, $12^{\text {th }}$ year, 41, 85-103.

Venkatesh, P. C., \& Chiang, R. (1986). Information asymmetry and the dealer's bid-ask spread: a case study of earnings and dividend announcements. The Journal of Finance, 41(5), 1089-11020. 